\title{
ADAPTATION OF MSMES BUSINESS IN NEW NORMAL CONDITIONS WITH THE IMPLEMENTATION OF STANDARD HEALTH PROTOCOLS
}

\author{
Andina Eka Mandasari ${ }^{1}$, Epi Dani Harison ${ }^{2}$, Dewi Permata Sari ${ }^{3}$, Nuryanti Taufik ${ }^{4}$ \\ 1,2,3,4 Program Studi Manajemen, Universitas Siliwangi \\ e-mail: ${ }^{1}$ andinaekamandasari@unsil.ac.id, ${ }^{2}$ epidaniharison@ unsil.ac.id, \\ 3.
}

\begin{abstract}
2020 is a tough year for all people in the world, including Indonesia. This is due to the emergence of a new virus called Covid-19. In order to avoid a wider spread of the virus, the Indonesian government adopted the PSBB or Large-Scale Social Restrictions policy, one of which limits direct contact between humans. One of the business sectors affected by this policy is MSMEs, where business is daily in nature and relies heavily on direct interaction. After almost two months of implementing the PSBB in Indonesia, the government finally announced a new condition for Indonesia, namely "New normal". In order to be able to survive with the new normal conditions, MSME actors are required to be able to adapt by prioritizing health protocols according to standards so that their business activities can continue to survive in competition. Therefore, a problem decoder is needed for MSMEs to be able to understand and apply standard health protocols in each of their business activities during the new normal period. This program provides guidance in the form of counseling and assistance to MSMEs regarding standard health protocols in business activities in new normal conditions so that they can adapt and maintain their business. In addition, Partners were also provided with standardized personal protective equipment and other health support tools that were able to help their business activities during the Covid-19 pandemic.
\end{abstract}

Keywords: MSME Business Adaptation, Health Protocol, New normal

\section{A. Introduction}

The year 2020 is quite a tough year for the entire world community, including Indonesia. This is due to the emergence of a new type of virus that was first discovered in the city of Wuhan, China, which was later named Covid-19. Covid-19 or Coronavirus Disease 2019 is a new disease that can cause respiratory problems and pneumonia. According to BBC News, Covid-19 has become epidemic and has spread to more than 200 countries around the world and one of them is Indonesia (The Visual and Data Journalism Team, 2020). Covid-19 cases in Indonesia as of June 17, 2020 have reached 41,431 positive cases with the death toll reaching 2,276 (Pemerintah DKI Jakarta, 2020) 
The spread of the virus is so massive and fast and has fatal consequences for the human body, forcing the world to make many changes, including making contact between humans to avoid a wider spread of the virus. Governments around the world have acted quickly by issuing policies that restrict their citizens from direct human contact. The Indonesian government chose to adopt the PSBB or Large-Scale Social Restrictions policy. These restrictions include holidays from schools and workplaces, restrictions on religious activities, restrictions on activities in public places or facilities, restrictions on socio-cultural activities, restrictions on transportation modes, and restrictions on other activities specifically related to defense and security aspects. The existence of this policy has a significant impact on people's lives, one of the most noticeable impacts is the increasingly sluggish economic and business activities in Indonesia. Many businesses suffer losses due to reduced purchasing power of the people, one of the most affected business sectors is MSMEs. The Indonesian Minister of
Cooperatives and Small and Medium Enterprises (Menkop UKM), Teten Masduki, said that this was because SME businesses were daily in nature and relied a lot on direct interaction, so that the PSBB and social distancing made demand drop drastically (CNBC Indonesia, 2020)

After almost two months of implementing PSBB in various provinces in Indonesia, the government finally announced a new condition for Indonesia, namely "New normal". New normal is a change in behavior to continue carrying out normal activities, but coupled with the application of health protocols to prevent the transmission of Covid-19 (WH, 2020) This new normal condition applies to all Indonesian people and all kinds of activities in it, including business activities carried out by MSMEs. In order to be able to survive with this new normal condition, MSME actors are required to be able to adapt by prioritizing health protocols in accordance with standards so that their business activities are able to continue to survive in the competition. One of the MSMEs that need to adapt the health protocol is the MSMEs in the 
culinary industry in Tasikmalaya City, especially those in the Siliwangi University Campus area which is one of the busiest centers in the city of Tasikmalaya. In addition, the culinary industry is a retail industry that is directly related to various consumers so that it really requires health protocol standards in conducting transactions and services to consumers.

Based on the explanation above, a program for MSMEs is needed, especially for MSMEs in the Tasikmalaya City Area to be able to understand and apply health protocols according to standards in each of their business activities. The activity is to provide guidance in the form of counseling and assistance regarding health protocol standards in business activities during the new normal period. Through this service activity, it is hoped that it can be one of the activities that provide practical benefits for MSME actors in the culinary industry so that they can continue to carry out business activities in new normal conditions

\section{B. Method of Implementation}

The method used in this service activity is through coaching in the form of counseling and assistance regarding health protocol standards in business activities in new normal conditions with the aim that partners are truly able to adapt and be able to maintain their business. Through this PbM program, the team will coordinate with health practitioners and business practitioners regarding good and correct health protocol standards.

Before the implementation of this program so that it can run smoothly and optimally, it is necessary to do proper preparation and planning. First, it is necessary to conduct field observations and analyze the knowledge of MSME actors regarding new normal conditions and health protocol standards. Then make a design/layout of standard health protocols for MSMEs. After that, prepare materials for video content socializing health protocols for MSMEs. In addition, preparing tools and materials used in implementing health protocol standards in business activities under new normal conditions.

Technically, the implementation of the activities of the $\mathrm{PbM}$ program begins with the provision of additional knowledge about new normal 
conditions and standard health protocols for MSMEs. After that, apply the tools and materials used for assistance regarding standard health protocols in business activities in new normal conditions. Prior to the implementation of health protocols, counseling was given by distributing health protocol socialization videos to MSME actors regarding the new normal and health protocol standards.

\section{Result and Discussion}

The first step in this community service activity is to coordinate with the two partners, namely Anggi and Edi Suryadi. Anggi is one of the street vendors located around the University of Siliwangi, while Edi Suryadi is one of the street vendors located around the University of Struggle. At this meeting, the team and partners discussed what equipment needed to be installed and used by partners, where the equipment had been adapted to health protocol standards. In addition, we discussed how the implementation of health protocols could be adapted by other street vendors around the Unsil and Unper campuses.

In order for this health protocol standard to be known by many street vendors, it is necessary to hold a forum through a digital media. Therefore, we ask for help from partners to record the street vendors around the Universitas Siliwangi and Universitas Perjuangan campuses. From the results of the data collection, it was found that the street vendors selling around Siliwangi University were Anggi, Nita Mulya, Bambang, Hani, Ahmad Sobirin, Yati, Yuyun, Opan, Epul, Nandar, Dadang, Jojoh and Yadi. Meanwhile, the street vendors around Universitas Perjuangan are Edi Suryadi, Titi, Usup, Rohedi, Aan, and Igit.

During this Covid-19 pandemic, all forms of direct interaction need to be limited. Therefore, the team conducted counseling on the application of standard health protocols for street vendors by distributing videos to street vendors. Before making the counseling video, the team looked for information on standard health protocols that could be applied by street vendors, including asking for advice from a health worker. One of the implementations of health protocols for street vendors is the adjustment of carts so that the distance between individuals can be maintained. The first step in adjusting the cart is to 
design a cart design concept for street vendors. The team designed to install plastic around the cart. To determine the suitability of the cart design with standard health protocols, the team consulted with a health worker. The results of the consultation turned out that in addition to installing around the cart, the team needed to install plastic to cover the merchandise storage area so that it could be kept clean. The following is a cart design concept that has been adapted to health protocol standards.

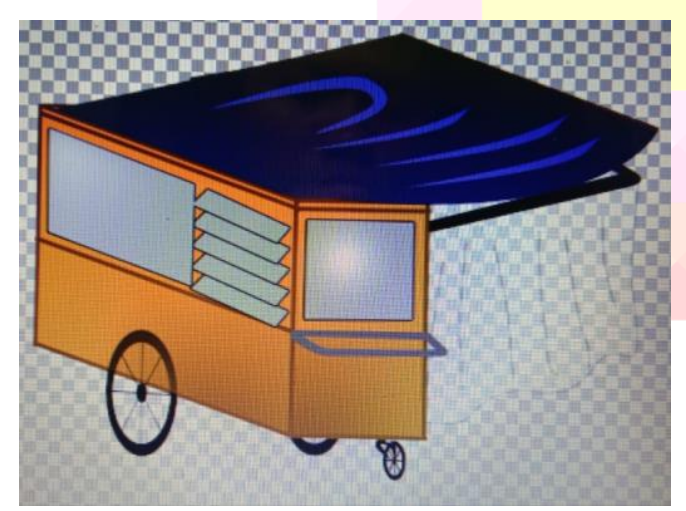

Figure 1. New Normal Street Vendor Cart Design

Materials and materials along with the socialization video script were handed over to a video creator who is a Siliwangi University student. The duration of the socialization video was made not too long, because it took into account the amount of quota needed to download the video. Furthermore, the video was distributed through the Whatsapp Group media which consisted of teams, partners, and street vendors who at the time of data collection had a Whatsapp number. If there are street vendors who do not have Whatsapp, then we ask the sales area representatives to be able to notify.

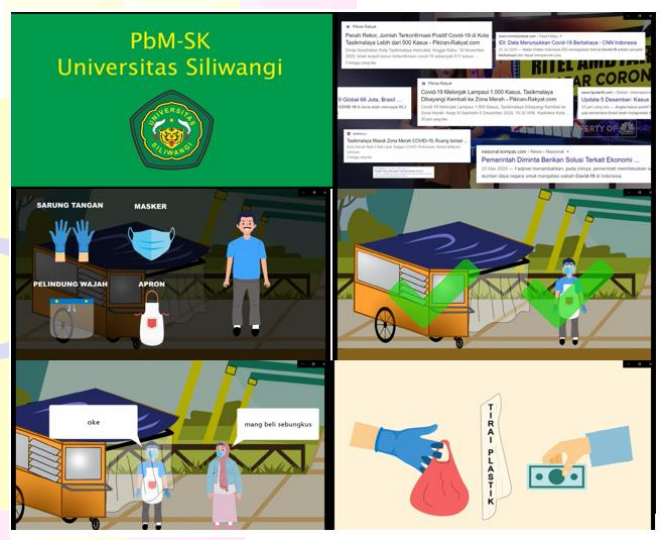

Figure 2. Socialization Video Clip High Light

The next step in the PbM-SK program is to install and provide health protocol equipment to partners. For the application of keeping a distance from consumers, plastic curtains are installed around the partner carts. Then for personal protection, partners are given health protocol tools such as gloves, masks, face shields, and aprons. After installing and providing health protocol equipment to partners, then installing and giving it to street vendors around Universitas Siliwangi and Universitas Perjuangan. The 
application of health protocols to fellow street vendors is carried out to increase the level of awareness of street vendors for the importance of implementing health protocols in their business activities. In addition, to increase the level of interest in using health protocol equipment for street vendors.

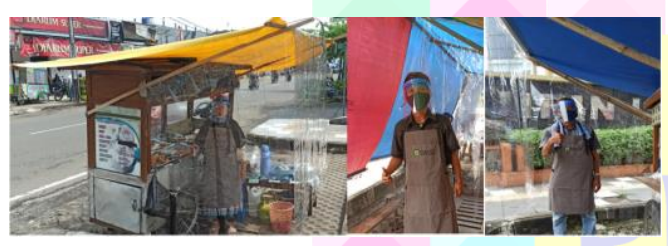

Figure 3. Application Health Protocol to Street Vendors

During the use of health protocol equipment, most of the street vendors did not experience any significant problems. Constraints that occur only when gloves are torn or dirty, masks are dirty, and face shields are damaged. For gloves, the team suggested replacing them with gloves made of plastic so that they are not too burdensome in terms of cost. The masks given are washable masks, so the team recommends washing them.

Furthermore, mica face shields were easy to replace, and the team practiced how to replace them. Although most of them did not experience any significant problems, considering the layout of the carts, some of them were not installed too close to the gas or stove. In addition, because it is too restrictive of movement, the plastic curtain is not installed on the back of the cart. However, the team still recommends carrying out transactions by maintaining a distance. The problem found is that not all street vendors are consistent in continuing to implement health protocols in their business activities, but most of them continue to apply. Therefore, the PbM-SK program is considered quite successful because the team has improved and introduced health protocols that need to be applied by street vendors. At least through this PbM-SK program, the team has increased awareness of street vendors and maybe even the surrounding community of the importance of implementing health protocols in the new normal conditions that are currently running.

\section{Conclusion}

The purpose of this PbM-SK program is so that the culinary industry MSME actors, especially street vendors, can still carry out business activities in new normal conditions so as to reduce the risk of spreading the 
Covid-19 virus. The implementation of community service which includes counseling and mentoring makes street vendors realize the importance of implementing health protocols in carrying out their business. The counseling given in the form of video can be widely distributed to street vendors other than around Unsil and Unper, it can even be distributed outside the city because there are no distance and time limits. Mentoring activities were carried out quite well, because the team could provide suggestions if there were obstacles or obstacles in implementing health protocols for street vendors. However, there was an adjustment in the installation of plastic curtains around the cart. The adjustment is adjusted to the condition of the cart. Overall, the $\mathrm{PbM}-\mathrm{SK}$ program is considered quite successful because the team has improved and introduced health protocols that need to be applied by street vendors. At least through this PbM-SK program, the team has increased awareness of street vendors and maybe even the surrounding community of the importance of implementing health protocols in the new normal conditions that are currently running.

\section{SUGGESTIONS}

Although this $\mathrm{PbM}-\mathrm{SK}$ activity has been able to increase the level of awareness of street vendors to implement health protocols in their business activities, it is still not evenly distributed. The team realized that this service program had limited manpower, time, and funds. In order to further increase the reach and even out the level of awareness of street vendors to implement health protocols in carrying out their business, support from the government is needed. The welfare of these MSMEs has escaped the government's attention, which in fact their income only depends on the daily results of their business. Therefore, it is hoped that the government can assist in increasing awareness and maintaining the consistency of MSME actors in implementing health protocols in their business activities.

\section{E. Aknowledgement}

The team would like to thank the Ministry of Education and Culture for providing financial support for this 
community service program. In addition, we would like to thank Universitas Siliwangi and the MSME business who have assisted in the implementation of this $\mathrm{PbM}-\mathrm{SK}$ activity.

\section{REFERENCES}

CNBC Indonesia. (2020). Ini Kata

Teten Masduki Soal Dampak

Covid-19 Bagi UMKM.

Retrieved June 15, 2020, from

https://www.cnbcindonesia.com/ news/20200429173402-8-

155339/ini-kata-teten-masduki-

soal-dampak-covid-19-bagi-

umkm

Pemerintah DKI Jakarta. (2020).

JAKARTA TANGGAP COVID-

19. Retrieved from

https://corona.jakarta.go.id/id

The Visual and Data Journalism

Team. (2020). Coronavirus

pandemic: Tracking the global

outbreak. Retrieved June 15,

2020, from

https://www.bbc.com/news/world

$-51235105$

WH, F. (2020). Mengenal Konsep

New Normal. Retrieved June 15,

2020, from

https://indonesia.go.id/ragam/ko moditas/ekonomi/mengenal-

konsep-new-normal 